\title{
PENGARUH PEMANFAATAN POWERPOINT TERHADAP PEMEROLEHAN BELAJAR MENGHITUNG VOLUME KUBUS DI KELAS V SDN 03 TEMPUNAK KABUPATEN SINTANG
}

\section{Oleh: Imus ${ }^{1}$}

\begin{abstract}
Abstrak : Tujuan penelitian ini adalah untuk mengetahui: 1) pemerolehan belajar pada siswa yang terlibat pembelajaran dengan memanfaatkan powerpoint di kelas V SDN 03 Tempunak, 2) perbedaan pemerolehan belajar antara siswa yang terlibat dengan memanfaatkan powerpoint dengan siswa yang terlibat pembelajaran konvensional, 3) Respon siswa terhadap pembelajaran yang memanfaatkan powerpoint.

.Penelitian ini dilaksanakan di SDN 03 Tempunak Kabupaten Sintang tahun pelajaran 2011/2012 dengan populasi siswa kelas V. Metode penelitian adalah kuasi eksperimen dan desain yang digunakan adalah Pre- Postes Control Group Design. Sampel penelitian siswa kelas V-A (eksperimen) dan kelas V-B (kontrol). Instrumen pengambilan data berupa tes pemerolehan belajar, angket respon Instrumen pelaksanaan penelitian berupa RPP, CD Multimedia. Teknik analisis data adalah uji-t.

Hasil penelitian menunjukkan bahwa: 1) skor rata-rata pemerolehan belajar siswa yang dilibatkan dalam pembelajaran dengan pemanfaatan powerpont mengalami perubahan 3 yaitu dari $6,18$ menjadi $9,18,2)$ perbedaan skor rata-rata antara siswa dengan pembelajaran memanfaatkan powerpont dan siswa pembelajaran konvensional t hitungnya 5,728, 3) respon siswa terhadap pembelajaran dengan memanfaatkan powerpoint dengan kriteria baik untuk ketiga aspek.
\end{abstract}

Kata kunci: pemanfaatan powerpoint, pemerolehan belajar dan respon

\section{PENDAHULUAN}

Peningkatan kompetensi atau kualitas sumber daya manusia Indonesia merupakan kebutuhan mutlak. Upaya peningkatan kualitas sumber daya manusia dapat dilakukan melalui berbagai jalur, diantaranya melalui

\footnotetext{
${ }^{I}$ Imus : Guru SDN 03 Tempunak Kabupaten Sintang
} 
pendidikan. Pendidikan memiliki nilai strategis dan mempunyai peran yang sangat penting sebagai suatu investasi masa depan

Proses pembelajaran SDN 03 Tempunak masih menerapkan bentuk formal (teori dan latihan), dalam menjelaskan suatu konsep pada pelajaran lebih banyak berceramah tanpa di dukung contoh-contoh yang konkret, seperti animasi dan video yang ada kaitannya dengan materi. Pada jenjang pendidikan dasar, pembelajaran masih dalam tahap operasional konkret yang sangat sulit menangkap pengetahuan yang bersifat abstrak. Pendekatan dan metode pembelajaran hendaknya dapat mengoptimalkan pemahaman peserta didik, sehingga pemahaman suatu konsep atau pengetahuan dibangun sendiri oleh peserta didik dengan bimbingan guru yang memanfaatkan media.

Agar penanaman konsep matematika semakin bertambah baik, salah satunya memanfaatkan media powerpoint. Pemanfaatan media powerpoint tersebut dirasa sangat penting untuk membantu guru dalam mentransfer pengetahuan kepada siswa. Dengan memafaatkan powerpoint yang tepat siswa akan mudah menerima apa yang diberikan guru dalam pembelajaran, dan diharapkan peserta didik dapat termotivasi dalam mengikuti proses pembelajaran, sehingga pada akhirnya dapat meningkatkan pemerolehan belajar.

\section{Masalah Penelitian}

Berdasarkan latar belakang masalah yang telah diuraikan di atas, masalah penelitian ini dapat dirumuskan sebagai berikut :

1. Bagaimanakah pemerolehan belajar menghitung volume kubus pada siswa yang terlibat dengan pembelajaran memanfaatkan powerpoint di kelas V SDN 03 Tempunak?

2. Apakah terdapat perbedaan pemerolehan belajar antara siswa yang terlibat dengan memanfaatkan powerpoint dengan siswa yang terlibat pembalajaran konvensional?

3. Bagaimana respon siswa terhadap pembelajaran yang memanfaatkan powerpoint?

\section{Media Pembelajaran}

Media adalah pembawa pesan yang berasal dari suatu sumber ke penerima pesan. Pembawa pesan dapat berupa orang atau benda. Dalam proses belajar mengajar penerima pesan adalah peserta didik.

Brigss (Arief Sadiman, 2008: 6) berpendapat bahwa"media adalah segala alat fisik yang dapat menyajikan pesan serta merangsang siswa untuk 
belajar". Media adalah perantara atau pengatar pesan dari pengirim ke penerima pesan.

\section{Pembelajaran Dengan Powerpoint}

Program Mikrosoft (Ms) powerpoint adalah sebuah program aplikasi keluarga Mikrosoft Office yang biasa digunakan sebagai media untuk presentasi. Program ini cukup sederhana untuk dipahami tetapi sangat menarik untuk mempresentasikan sesuatu. Sehingga, program ini sangat cocok digunakan sebagai media pembelajaran di dalam kelas.

Salah satu kelebihan program Ms powerpoint adalah memiliki fitur animasi yang sederhana yaitu suatu ojek dapat muncul (Entrace) dari tidak ada , berubah (Emphasis), menghilang (Exit) dan bergerak (Motion Path). Apabila keempat fitur ini digabungkan akan menghasilkan suatu animasi yang cukup cantik. Selain keempat fitur tersebut, dapat diatur juga lamanya objek beranimasi.

\section{Pembelajaran Matematika}

Menurut Gredler dalam Yatim ( 2009:6), " Belajar adalah perubahan tingkah laku sebagai akibat dari interaksi antara stimulus dan respon. Pendapat lain diungkapkan oleh H.C. Witherington, James O Whittaker dalam Aunurrahman (2008:35) menyatakan " Belajar adalah proses dimana tingkah laku ditimbulkan atau diubah melalui latihan atau pengalaman ".

Matematika adalah terjemahan dari Mathematics (dalam http:// pinggiralas.blogspot.com, 12 Juli 2011). Matematika lebih dari pada aritmetika, yakni ilmu tentang kalkulasi / perhitungan. Ia lebih dari pada aljabar, yang merupakan bahasan lambang, operasi dan relasi. Namun arti atau definisi yang tepat dari matematik tidak dapat diterapkan secara eksak (pasti) dan singkat. Matematika adalah cara/metode berpikir dan bernalar.

Jadi matematika adalah bahasa yang melambangkan (simbol) serangkaian makna dari pernyataan yang ingin disampaikan.

\section{Pembelajaran Menghitung Volume Kubus}

Mengitung volume kubus adalah kompetensi dasar materi pembelajaran matematika kelas V SD semester 1 yang merupakan dasar untuk memahami materi selanjutnya. Untuk itu dalam pembelajaran mengitung volume kubus, khususnya anak SD, guru hendaknya dalam menyampaikan perlu sekali menyelami bahasa anak. Dalam hal ini yang 
dimaksud adalah bahasa yang digunakan peserta didik atau kemampuan memahami bahasa sesuai taraf perkembangannya.

\section{Respon}

Menurut Sarlito (1987), setiap tingkah laku pada hakekatnya merupakan tanggapan/balasan (respon) terhadap stimulus. Pendapat selaras diungkap oleh Mar'at ( www.scribd.com/doc) yang menyatakan bahwa respon merupakan reaksi akibat penerimaan stimulus, dimana stimulus adalah berita, pengetahuan, informasi, sebelum diproses atau diterima oleh indranya.

Kisi-kisi Respon siswa yang akan diamati ada beberapa aspek yaitu hasrat dan kemauan, perasaan senang dan kecenderungan melakukan kegiatan (Musrini, 2009: 112)Aspek hasrat dan kemauan dengan lima indikator yaitu: konsentrasi, kesungguhan, cara menyikapi masalah, kedisiplinan belajar dan kateraturan belajar. Aspek perasaan senang juga meliputi lima indikator yaitu: kreativitas, perhatian, kegemaran, ketangguhan dan ketertarikan. Sedangkan aspek yang ketiga adalah kecenderungan melakukan kegiatan dengan indikator semangat, kegairahan, kesiapan, keinginan dan kecekatan.

\section{Pemerolehan Belajar}

Setelah selesai belajar, penampilan yang dapat diamati sebagai pemerolehan belajar adalah kemampuan-kemampuan (capabilities). Kemampuan-kemampuan tersebut dibedakan berdasarkan atas kondisi mencapai kemampuan tersebut berbeda-beda. Ada lima kemampuan (kapabilitas) sebagai pemerolehan belajar yang diberikan Gagne dalam Nana Sudjana (2009: 22) yaitu :1) keterampilan intelektual, 2) strategi kognitif, 3) informasi verbal, 4) ketrampilan motorik, dan 5) sikap.

\section{Kerangka Berpikir}

Pemanfaatan powerpoint memungkinkan membantu peserta didik dalam memahami bahan ajar yang disampaikan guru, karena dengan memanfaatkan powerpoint siswa dapat mendengar dan melihat sehingga keterlibatan indera siswa lebih banyak dibandingkan tanpa memanfaatkan powerppoint . Keterlibatan indera dalam proses pembelajaran membantu siswa untuk memahami bahan ajar yang disampaikan oleh guru.

\section{METODE PENELITIAN}

Metode penelitian yang digunakan adalah metode eksperimen dengan dua perlakuan yaitu kelompok I (kelompok eksperimen) merupakan 
kelompok yang diberi perlakuan pembelajaran dengan memanfaatkan powerpoint dan kelompok II (kelompok kontrol) merupakan kelompok yang dalam pembelajaran tanpa memanfaatkan powerpoint

Populasi penelitian ini adalah seluruh siswa kelas V SDN 03 Tempunak tahun 2011/2012 yang terdiri dari 3 kelas dengan jumlah 66 siswa. Sampel penelitian adalah siswa Kelas VA sebagai kelas eksperimen dan VB sebagai kelas kontrol. Penentuan kelas eksperimen dan kelas kontrol menggunakan intact group yang dipilih dengan cara undian

Dalam penelitian ini tes pemerolehan belajar yang peneliti gunakan adalah tes obyektif dengan setiap jawaban benar diberi skor 1, dan setiap jawaban salah diberi skor 0 . Sehingga untuk menghitung tingkat reliabilitas tes ini digunakan rumus Kuder Richadson 20 ( KR-20)

\section{Analisis Data}

Untuk menguji siginifikan perbedaan hasil pengukuran terhadap subyek yang saling bebas / independen dipergunakan rumus uji t Skor pretes $\left(\mathrm{X}_{1}\right)$, skor postes $\left(\mathrm{X}_{2}\right)$.

\section{HASIL PENELITIAN DAN PEMBAHASAN}

Skor pemerolehan belajar didapat setelah memberikan tes yang dilakukan sebelum perlakuan (pretes ) dan setelah perlakuan (postes). Soal tes ada 15 butir, jawaban benar skor 1 dan jawaban salah skor 0 . jika siswa menjawab benar semua maka skor maksimum 15 , dan jika salah semua maka skor minimum 0. Berdasarkan analisis skor pemerolehan belajar yang dilaksanakan pada kedua kelas :

\begin{tabular}{|l|c|c|c|c|c|c|}
\hline \multirow{2}{*}{} & \multicolumn{2}{|c|}{ Pretest } & \multicolumn{2}{c|}{ Postest } & \multicolumn{2}{c|}{ Perubahan } \\
\cline { 2 - 7 } & Skor & $\%$ & Skor & $\%$ & Skor & $\%$ \\
\hline Kelas eksperimen & 6.18 & 18.18 & 9.18 & 72.72 & 3.00 & 2728 \\
\hline Kelas Kontrol & 6.27 & 36.36 & 8 & 22.72 & 1.73 & 18.82 \\
\hline
\end{tabular}

Dari data pada tabel tersebut, dapat kita lihat ternyata skor rata-rata pretes untuk kelas eksperimen $(6,18)$ dan skor rata-rata kelas kontrol $(6.27)$ relatif sama (selisih 0.09 ) artinya rata-rata pemerolehan belajar kedua kelas hamper sama dan setelah perlakuan skor rata -rata pemerolehan belajar untuk kelas eksperimen $(9,18)$ sedangkan skor rata-rata untuk kelas kontrol ( 8.0) kedua kelompok berbeda (selisih 1,18 ) artinya rata-rata pemerolehan belajar kelas eksperimen lebih tinggi (1.18) dari kelas kontrol . 


\section{Respon Siswa}

Angket respon siswa dalam penelitian ada tiga aspek baik untuk kelas eksperimen maupun kontrol yaitu 1) Hasrat dan kemauan, 2) perasaan senang, dan 3) kecenderungan melakukan kegiatan, dirinci menjadi 15 indikator dan dijabarkan dalam 30 item pernyataan.

Dari 30 butir item angket respon skor maksimumnya setiap butir 5 sedangkan skor minimumnya 1, sehingga skor yang dapat diraih siswa untuk skor maksimum 150 dan skor minimum 30.

\begin{tabular}{|l|c|c|c|}
\hline & $\begin{array}{c}\text { Aspek Hasrat } \\
\text { dan Kemauan }\end{array}$ & $\begin{array}{c}\text { Perasaan } \\
\text { Senang }\end{array}$ & $\begin{array}{c}\text { Kecenderungan } \\
\text { Melakukan kegiatan }\end{array}$ \\
\hline Rata-rata & 4.002 & 3.90 & 3.97 \\
\hline
\end{tabular}

Berdasarkan hasil uji t kelas ekeperimen diperoleh angka t hitung (9.374) lebih besar dari nilai $t$ tabel $(2,08)$, artinya hipotesis yang menyatakan ada perbedaan secara signifikan skor pemerolehan belajar dengan pemanfaaran powerpoint terbukti : Perbedaan Pemerolehan Belajar antara siswa yang pembelajarannya dengan memanfaatkan powerpoint dan pembelajaran konvensional

Uji $t$ untuk kelas rata-rata pemerolehan belajar matematika memanfaatkan powerpoint lebih tinggi dibanding dengan skor rata-rata pemerolehan belajar Matematika dengan konvensional

Perbedaan pemanfaatan powerpoint ternyata memberikan pengaruh yang berbeda terhadap pemerolehan belajar matematika. Hal ini sesuai dengan pendapat Soeparno ( 1987) bahwa alasan memilih media dalam pembelajaran harus disesuaikan dengan karakteristik siswa. Media yang digunakan untuk menyampaikan informasi tertentu harus disesuaikan dengan situasi dan kondisi tempat media tersebut digunakan agar media tersebut dapat memberikan manfaat yang sesuai dengan karakteristik siswa tersebut.. Oleh karena itu pemilihan media harus tepat agar berhasil guna dan berdaya guna. Powerpoint dan media teks merupakan dua media yang memiliki karakteristik berbeda dalam meyampaikan informasi sesuai dengan kondisi dan situasi siswa yang beragam sehingga diharapkan memberikan pemerolehan belajar yang berbeda

Berdasarkan skor rata-rata pemerolehan belajar matematika yang lebih tinggi melalui pemanfaatan powerpoint disebabkan oleh ketertarikan siswa terhadap media pembelajaran powerpoint dengan powerpoint siswa lebih tertarik untuk mengikuti pembelajaran, powerpoint yang mempunyai kelebihan dapat menampilkan teks, gambar grafik, dan suara tebih banyak 
memberikan kesan kepada siswa, sehingga hal tersebut berdampak pada pemerolehan belajar.

Dengan memanfaatkan powerpoint siswa dapat melihat, mendengar, bahkan melakukan interaksi, dengan demikian keterlibatan indera siswa dalam penggunaan media powerpoint lebih banyak dibandingkan dengan media lain seperti media teks. Dengan powerpoint guru dapat membuat animasi yang sesuai dengan bahan ajar, dan dengan memanfaatkan powerpoint guru dapat melakukan presentasi yanh lebih efektif, hal ini sesuai dengan teori yang dikemukakan oleh Yudhi Munadi ( 2008: 148)., yang menyatakan :

Multimedia pembelajaran powerpoint adalah media yang mampu melibatkan banyak indera dan organ tubuh selama proses pembelajaran berlangsung. Media powerpoint merupakan kombinasi dari suara, gambar, dan teks. Media powerpoint adalah kombinasi dari paling sedikit dua media input atau output dari data, media ini dapat berupa audio, animasi, video, teks, grafik dan gambar.. Media powerpoint merupakan alat yang menciptakan presentasi yang dinamis dan interaktif yang mengkombinasikan teks, grafik, animasi, audio dan gambar video

Dengan memanfaatkan media powerpoint maka siswa lebih tertarik dalam mengikuti pembelajaran, ketertarikan siswa tersebut disebabkan media powerpoint merupakan sarana pembelajaran yang lebih hidup dan presentatif, sehingga media powerpoint banyak membantu siswa dan guru dalam proses pembelajaran

Pada pembelajaran memanfaatkan media powerpoint siswa tampak antusias dan tertarik dengan proses yang dilakukan secara mandiri melalui tampilan yang menarik. Kesan bahwa Matematika merupakan pelajaran yang menakutkan tidak tampak pada proses pembelajaran dengan media powerpoint . Kondisi ini merupakan salah satu tujuan pembelajaran dengan media menarik dan diharapkan pemerolehan belajar dapat meningkat.

\section{Respon Siswa Terhadap Pembelajaran dengan Memanfaatkan Powerpoint}

Dari tiga aspek respon siswa yaitu: aspek hasrat dan kemauan, perasaan senang aspek kecenderungan melakukan kegiatan kesemuanya dengan kriteria baik, artinya respon siswa terhadap pembelajaran dengan memanfaatkan powerpoint adalah baik.

\section{KESIMPULAN}

Sejalan dengan masalah dan hasil analisis data dapat disimpulkan bahwa pembelajaran Matematika dengan memanfaatkan powerpoint berpengaruh 
signifikan dalam meningkatkan pemerolehan belajar. Secara khusus diperoleh kesimpulan sebagai berikut :

1. Skor rata-rata pemerolehan belajar kelas dengan pemanfaatan powerpoint menunjukkan peningkatan yang signifikan yaitu 3, sebelum memanfaatkan powerpoint (pretest) skor rata-ratanya 6.18 setelah pemanfaatan powerpoint skor rata-ratanya (postes) 9.18 dengan nilai uji $t$ hitung 9.374 jauh lebih besar dari t tabel 2.08

2. Perbedaan skor rata-rata antara kelas yang pembelajarannya dengan memanfaatkan powerpoint dan kelas konvensional ditunjukkan dengan nilai uji t hitung yaitu 11.13

3. Respon siswa terhadap pembelajaran yang memanfaatkan powerpoint Pembelajaran dengan memanfaatkan powerpoint pada kelas eksperimen menunjukkan respon dengan kriteria baik, baik untuk aspek hasrat, perasaan senang dan aspek kecenderungan melakukan kegiatan

\section{DAFTAR PUSTAKA}

Arief S Sadiman, (2008), Media Pendidikan, pengertian, pengembangan, dan pemanfaatannya, Jakarta: Pustekom Diknas dan PT Raja Grafindo Perkasa

Aunurrahman, 2008, Belajar dan Pembelajaran, Bandung: Alfabeta

Azhar Arsyad, 2008, Media Pembelajaran, Jakarta, RajaGrafindo Persada

Heinich, dkk, 1996, Instructional Media and Technologies for Learning, Seventh Edition Upper Sadle River, New Jersey, Ohio Merril Prentice Hall

.Musrini, 2009, Pengaruh Penggunaan Media Pembelajaran Model dan Gambar Terhadap Prestasi Belajar Ilmu Pengetahuan Alam Ditinjau dari Minat Belajar Siswa Tidak diterbitkan. Surakarta: Universitas Sebelas Maret

Panduan Teknis Menulis Proposal Tesis, 2011, Pontianak: Universitas Tanjungpura

Sarlito Wirawan, 1984, Pengantar Umum Psikologi, Jakarta: Bulan Bintang

Smaldino,S,E, Russel, J, D, Heinich, R and Molenda, M, 1996, Instructional Technology and Media for Learning, New Jersey: Prentice Hall

Yatim Riyanto, 2009, Paradigma Baru Pembelajaran, Jakarta: Kencana Prenada Media Group 
http://techonly13.wordpress.com/2010/10/08/hakikat-matematika/ ， diunduh 10 Juli 2011

http://www.scribd.com/doc/respn siswa, diunduh 5 November 2011 